Article

\title{
Bacterial Nanocellulose Nitrates
}

\author{
Vera V. Budaeva ${ }^{1, *}$, Yulia A. Gismatulina ${ }^{1}$, Galina F. Mironova ${ }^{1}$, Ekaterina A. Skiba ${ }^{1}$, \\ Evgenia K. Gladysheva ${ }^{1}$, Ekaterina I. Kashcheyeva ${ }^{1}$, Olga V. Baibakova ${ }^{1}$, Anna A. Korchagina ${ }^{1}$, \\ Nadezhda A. Shavyrkina ${ }^{1,2}$, Dmitry S. Golubev ${ }^{1,2}$, Nikolay V. Bychin ${ }^{1}$, Igor N. Pavlov ${ }^{1}$ \\ and Gennady V. Sakovich ${ }^{1}$ \\ 1 Laboratory of Bioconversion, Institute for Problems of Chemical and Energetic Technologies, Siberian Branch \\ of the Russian Academy of Sciences (IPCET SB RAS), Biysk 659322, Altai Krai, Russia; \\ julja.gismatulina@rambler.ru (Y.A.G.); yur_galina@mail.ru (G.F.M.); eas08988@mail.ru (E.A.S.); \\ evg-gladysheva@yandex.ru (E.K.G.); massl@mail.ru (E.I.K.); olka_baibakova@mail.ru (O.V.B.); \\ yakusheva89_21.ru@mail.ru (A.A.K.); 32nadina@mail.ru (N.A.S.); reklatekoy@gmail.com (D.S.G.); \\ nbych@ya.ru (N.V.B.); pawlow-in@mail.ru (I.N.P.); admin@ipcet.ru (G.V.S.) \\ 2 Biysk Technological Institute, Polzunov Altai State Technical University, Biysk 659305, Altai Krai, Russia \\ * Correspondence: budaeva@ipcet.ru
}

Received: 25 October 2019; Accepted: 24 November 2019; Published: 27 November 2019

\begin{abstract}
Bacterial nanocellulose (BNC) whose biosynthesis fully conforms to green chemistry principles arouses much interest of specialists in technical chemistry and materials science because of its specific properties, such as nanostructure, purity, thermal stability, reactivity, high crystallinity, etc. The functionalization of the BNC surface remains a priority research area of polymers. The present study was aimed at scaled production of an enlarged BNC sample and at synthesizing cellulose nitrate $(\mathrm{CN})$ therefrom. Cyclic biosynthesis of BNC was run in a semisynthetic glucose medium of 10-72 L in volume by using the Medusomyces gisevii Sa-12 symbiont. The most representative BNC sample weighing $6800 \mathrm{~g}$ and having an $\alpha$-cellulose content of $99 \%$ and a polymerization degree of 4000 was nitrated. The nitration of freeze-dried BNC was performed with sulfuric-nitric mixed acid. BNC was examined by scanning electron microscopy (SEM) and infrared spectroscopy (IR), and CN was explored to a fuller extent by SEM, IR, thermogravimetric analysis/differential scanning analysis (TGA/DTA) and ${ }^{13} \mathrm{C}$ nuclear magnetic resonance (NMR) spectroscopy. The three-cycle biosynthesis of BNC with an increasing volume of the nutrient medium from 10 to $72 \mathrm{~L}$ was successfully scaled up in nonsterile conditions to afford $9432 \mathrm{~g}$ of BNC gel-films. CNs with a nitrogen content of $10.96 \%$ and a viscosity of $916 \mathrm{cP}$ were synthesized. It was found by the SEM technique that the CN preserved the 3D reticulate structure of initial BNC fibers a marginal thickening of the nanofibers themselves. Different analytical techniques reliably proved the resultant nitration product to be $\mathrm{CN}$. When dissolved in acetone, the $\mathrm{CN}$ was found to form a clear high-viscosity organogel whose further studies will broaden application fields of the modified BNC.
\end{abstract}

Keywords: carbon nanomaterials; bacterial nanocellulose; Medusomyces gisevii; nitration; nitric-sulfuric acids; cellulose nitrates; surface morphology; scale-up

\section{Introduction}

Research and advances in the field of bacterial nanocellulose (BNC) have been gaining fast pace in recent times, indicating the significance of this unique biopolymer. BNC has received global interest because of its physicomechanical and chemical properties, such as 3D porous structure, high purity, high mechanical strength and flexibility, high crystallinity, high specific surface area, high water-holding capacity and polymerization degree, as well as perfect biocompatibility [1]. 
Both as an individual material and in BNC-based composites, BNC has numerous applications in medicine (wound-healing materials, artificial skin, artificial blood vessels, tissue engineering biomaterials) [2-5], food industry [6], electronic industry [7], textile industry [8], paper industry, cosmetics and so forth $[1,9]$. Different modifications of BNC can expand its use to even more fields of promising applications. As any other cellulose, BNC can also be carboxymethylated, acetylated, phosphorylated, and modified by other reactions to produce a variety of BNC derivatives [10]. That being said, these derivatives will also exhibit unique properties, as they are derived from unique BNC. The promising direction in chemical modification of BNC is its nitration. Cellulose nitrates (CNs), owing to their unique physical properties, are among most essential cellulose derivatives widely used for industrial and defense purposes [11-13]. The synthesis of CNs from BNC will afford CNs with novel functionalities and properties, and will broaden the range of their application [10].

Initial results on the nitration of BNC are currently available. Yamamoto et al. [14] described the nitration of $\mathrm{BNC}$ with concentrated nitric acid in dichloromethane at $4{ }^{\circ} \mathrm{C}$ by varying the nitrating mixture composition and nitration time. Other researchers $[11,15,16]$ obtained CNs by nitrating BNC with mixed nitric-sulfuric acid. The absence of a detailed description and the small quantity of the resultant $\mathrm{CNs}$ are the bottlenecks of the listed studies, which does not allow their full characterization. Luo et al. [11] prepared CNs from bacterial cellulose with a nitrogen content of $11.97-12.88 \%$, and those authors believe the $\mathrm{CNs}$ have a rigid molecular chain in a dilute acetone solution. These findings can be used in further investigation of rheological and technological properties of BNC-based CNs and in search of their application field.

The literature overview on BNC nitration has revealed that full characterization of the $\mathrm{CNs}$ synthesized from BNC is absent, and the bacterial cellulose nitration issue is understudied. This is quite natural because BNC has moisture of $98-99 \%$, while nitration requires dry BNC. The functionalization of the BNC surface makes sense only when the BNC biosynthetic process is systemized through to the production in required volumes [17]. Correspondingly, to achieve representative results and run necessary nitration replicates, it is required at the least that the BNC biosynthesis process be scaled up in volume.

Individual strains are chiefly utilized as the BNC-producing microorganism. However, such microorganisms are distinguished by a spontaneous decline in cellulose-synthesizing capability and by an appreciable decrease in productivity in the manufacturing environment $[18,19]$. Therefore, a number of scientific teams put forward a concept of using microbial consortia whose adaptivity is enhanced by synergistic effects in the total metabolism [1], which is especially crucial for alternative nutrient broths prepared from residues of existing food, textile and hydrolytic industries, or prepared from worthless cellulosic raw materials [20]. The peculiar feature of the present study is that a Medusomyces gisevii symbiont was employed, also known as kombucha (tea fungus) [21]. Since this cellulose-producing symbiont exhibits adaptivity and capability of functioning under extreme conditions (for example, in heavy water) [22] and is tolerant to contamination, we have made an assumption that it can function in nonsterile conditions. The demand for such cellulose-producing strains was mentioned in the world literature [23]. In this case, BNC is synthesized for further use in technical chemistry to obtain a derivative, such as cellulose nitrate $(\mathrm{CN})$; therefore, the possibility of working in nonsterile conditions is extremely important because it allows one not only to set up sustainable manufacture, but also reduce operational costs.

We have previously shown that BNC produced by Medusomyces gisevii has a high crystallinity index of $86-93 \%$ and is composed of $93.6-100 \% \mathrm{I} \alpha$-phase [24,25]. The triclinic cellulose $\mathrm{I} \alpha$ is less stable than the monoclinic cellulose I $\beta$, and hence, it has a higher reactivity; therefore, the I $\alpha$-phase will be the site of primary reaction, which is essential for derivatization. This is another more argument for choosing the symbiont.

The present study was aimed at producing an enlarged BNC sample and synthesizing $\mathrm{CN}$ therefrom. 


\section{Materials and Methods}

All the reagents and materials used in this study were procured from AO Vekton, Russia.

\subsection{Biosynthesis of $B N C$}

\subsubsection{BNC-Producing Symbiont}

Medusomyces gisevii Sa-12, a BNC-producing strain, was procured from the All-Russian Collection of Industrial Microorganisms (State Research Institute of Genetics and Selection of Industrial Microorganisms of the National Research Center "Kurchatov Institute", Moscow, Russia). The symbiont was maintained by the subculture method in a semisynthetic nutrient broth consisting of glucose $(20 \mathrm{~g} / \mathrm{L})$ and black tea extract $(5 \mathrm{~g} / \mathrm{L})$ [26], which is a conventional medium for a symbiont [27]. The conditions were as follows: The medium was $1 \mathrm{~L}$ in volume; the strain was seeded once a week; the temperature was $28^{\circ} \mathrm{C}$; stationary culture; and the physiological condition of the symbiont was controlled by microscopy. The active acidity was not controlled intentionally, as any intervention adversely affects the BNC-producing capability of the symbiont [26,28].

\subsubsection{Synthesis of BNC Gel-Films}

BNC was prepared in a cyclic manner whereby the nutrient medium was increasing in volume with each subsequent culturing. The variable culture parameters are summarized in Table 1.

Table 1. Cyclic culture of bacterial nanocellulose (BNC).

\begin{tabular}{ccccccc}
\hline $\begin{array}{c}\text { Culture } \\
\text { Cycle }\end{array}$ & $\begin{array}{c}\text { Culture Vessel } \\
\text { Dimensions } \\
(\mathbf{c m} \times \mathbf{c m} \times \mathbf{~ c m})\end{array}$ & $\begin{array}{c}\text { Culture } \\
\text { Vessel } \\
\text { Volume (L) }\end{array}$ & $\begin{array}{c}\text { Fullness } \\
\text { Coefficient of } \\
\text { Culture Vessel }\end{array}$ & $\begin{array}{c}\text { Qnty of } \\
\text { Vessels (pcs) }\end{array}$ & $\begin{array}{c}\text { Total Volume of } \\
\text { Nutrient } \\
\text { Medium (L) }\end{array}$ & $\begin{array}{c}\text { Thickness } \\
\text { of Medium } \\
\text { Layer (cm) }\end{array}$ \\
\hline I & $49.5 \times 69.5 \times 5.0$ & 17 & 0.59 & 1 & 10 & 2.9 \\
II & $36.5 \times 36.5 \times 8.3$ & 11 & 0.59 & 3 & 19.5 & 4.9 \\
III & $140 \times 140 \times 5.3$ & 104 & 0.69 & 1 & 72 & 3.7 \\
\hline
\end{tabular}

The culture in each cycle was run under stationary conditions for seven days at $20-24{ }^{\circ} \mathrm{C}$ in vessels made of stainless steel. The inoculum dosage in each cycle was $10 \%$ of the nutrient medium volume, in which case the growth medium obtained in the first culture cycle was used as the inoculum for the second cycle, and the growth medium from the second cycle was used as the inoculum for the third cycle.

The growth medium was analyzed for glucose concentration by UNICO UV-2804 spectrophotometer (United Products and Instruments, Inc., USA) using 3,5-dinitrosallycilic acid as the reagent (Panreac, Spain) [29]. The active acidity level of the culture medium was measured potentiometrically by an I-160MI ion meter (OOO Izmeritelnaya Tekhnika, Russia). The microbial abundance was analyzed by microscopy of the growth medium samples on an Optika B-150 instrument (Optika, Italy). The cell count was done in a Goryaev chamber.

\subsubsection{Washing of BNC}

The passive purification technique was used because it can preserve the BNC structure to the full. The passive purification implies passive diffusion of dilute alkaline and acid solutions and distilled water, that is, the holding of BNC in the respective solutions for a prolonged time at $20-24{ }^{\circ} \mathrm{C}$ without stirring. The washing intensification (by increasing the alkali concentration or temperature) is known to bring about possible alterations in the structure of bacterial cellulose [30,31]. Here, BNC was washed in a $2 \% \mathrm{NaOH}$ solution at $20-24{ }^{\circ} \mathrm{C}$, and since the BNC gel-films had a large weight and thickness, the washing solutions were replaced 2-3 times. Then, BNC was washed with water to decolor BNC completely. Afterwards, decationation with a $0.1 \% \mathrm{HCl}$ solution was performed, and $\mathrm{BNC}$ was then washed with distilled water until neutral wash waters. 


\subsubsection{Calculation of BNC Yield}

The yield of BNC (\%) was calculated by the Equation (1):

$$
\eta=\frac{m_{B N C}}{C_{g} \cdot V \cdot 0.9} \cdot 100
$$

where $\eta$ is the BNC yield (\%), $m_{B N C}$ is the weight of the BNC sample on an oven-dry basis $(\mathrm{g}), C_{g}$ is the glucose concentration in the medium $(\mathrm{g} / \mathrm{L}), V$ is the volume of the medium $(\mathrm{L})$, and 0.9 is the conversion factor attributed to the detachment of the water molecule by polymerization of glucose into cellulose. This calculation method is a modification of classical Hestrin and Schramm's calculations [32] widely used in the biosynthesis of BNC [33]. The factor of 0.9 should be taken into account from the standpoint of stoichiometry of the BNC biosynthesis from glucose molecules.

\subsubsection{Quality Attributes of BNC}

The $\alpha$-cellulose content in the BNC was determined by a method whereby cellulose is treated with a $17.5 \mathrm{wt} \% \mathrm{NaOH}$ solution $(45 \mathrm{~mL}$ ) for $45 \mathrm{~min}$, and the undissolved residue is quantified after washing with $9.5 \mathrm{wt} \% \mathrm{NaOH}$ and water, and then dried [34].

BNC degree of polymerization (DP) was determined by the outflow time of cellulose solution in cadoxene (cadmium oxide in ethylenediamine) from a VPZh-3 capillary viscometer (Ecokhim, Russia) with a capillary diameter of $0.92 \mathrm{~mm}$ [35].

All experiments were done in triplicate and data were expressed as average values.

\subsubsection{Examination of BNC Structure}

The surface morphology of BNC fibers was examined by scanning electron microscopy (SEM) on a GSM-840 electron microscope (Jeol, Japan) after sputter-coating a Pt layer of 1-5 nm thick. The diameter of microfibrils was defined as an average of 50 measurements in the SEM image at $\times 10,000$ zoom.

Infrared (IR) spectra of BNC were taken on an Infralum FT-801 spectrometer (OOO NPF Lumex-Sibir, Russia) operating at $4000-500 \mathrm{~cm}^{-1}$. For IR spectroscopy, BNC was pressed into pellets with potassium bromide in a BNC:KBr ratio of 1:150.

\subsubsection{Freeze-Drying of BNC}

BNC was freeze-dried in a Bio-Rus-4SFD (distributed by OOO Bio-Rus, Russia) freeze-dryer as follows: BNC was frozen at -40 to $-50^{\circ} \mathrm{C}$ and held at this temperature for $12 \mathrm{~h}$, then BNC was gradually heated from $-50^{\circ} \mathrm{C}$ to $+25^{\circ} \mathrm{C}$ for $24 \mathrm{~h}$.

\subsection{Nitration of $B N C$}

\subsubsection{Preparation of BNC for Nitration}

Prior to nitration, the BNC freeze-dried to moisture of at most $5 \%$ was cut with scissors into $3 \mathrm{~mm}$ $\times 5 \mathrm{~mm}$ rhombic pieces.

\subsubsection{Nitration and Stabilization of BNC}

$\mathrm{BNC}$ was nitrated under conditions required for the synthesis of low-nitrogen $\mathrm{CN}$. A weighed portion of BNC (20 g) was treated with commercial sulfuric-nitric mixed acid containing $14 \%$ water. The mass ratio of $\mathrm{BNC}$ to mixed acid was $1: 50$, the temperature was $25-30^{\circ} \mathrm{C}$, and nitration time was $40 \mathrm{~min}$. The $\mathrm{CN}$ sample washed until neutral wash waters were stabilized with constant stirring as follows: Treatment with water for $1 \mathrm{~h}$ at $85-95^{\circ} \mathrm{C}$, then treatment with $0.03 \%$ sodium carbonate solution for $3 \mathrm{~h}$ at $85-95^{\circ} \mathrm{C}$, and then again with water for $1 \mathrm{~h}$ at $85-95^{\circ} \mathrm{C}$. 
The $\mathrm{CN}$ sample dried at $100 \pm 5^{\circ} \mathrm{C}$ was analyzed. All experiments were done in triplicate and data were expressed as average values.

\subsubsection{Calculation of CN Yield}

The yield of $\mathrm{CN}(\%)$ was calculated by the Equation (2):

$$
W=\frac{m_{C N}}{m_{B N C}} \cdot 100
$$

where $W$ is the yield of $\mathrm{CN}(\%), m_{C N}$ is the weight of the $\mathrm{CN}$ sample $(\mathrm{g})$, and $m_{B N C}$ is the weight of the BNC sample for nitration $(\mathrm{g})$.

The degree of substitution was calculated from the nitrogen content by Equation (3) [36]:

$$
D S=\frac{3.6[N]}{31.1-[N]} .
$$

\subsubsection{Analysis of $\mathrm{CN}$}

The nitrogen content was quantified by the ferrous sulfate method $[37,38]$, which relies on saponifying $\mathrm{CN}$ with concentrated sulfuric acid and on reducing the formed nitric acid with iron (II) sulfate to nitrogen oxide that generates, in excess of iron (II) sulfate, a $[\mathrm{Fe}(\mathrm{NO})] \mathrm{SO}_{4}$ complex compound that turns the solution yellow-pink. The $\mathrm{CN}$ viscosity was determined by measuring the flow time of a $2 \% \mathrm{CN}$-acetone solution out of a VPZh-1 capillary viscometer (Ecokhim, Russia). The CN solubility in the alcohol-ester mixture was measured by filtering the $\mathrm{CN}$ residue insoluble in alcohol-ester mixture, followed by drying and weighing. The solubility in acetone $(1 \mathrm{~g} \mathrm{CN}$ and $50 \mathrm{~mL}$ acetone) was measured by filtration of the acetone-insoluble $\mathrm{CN}$ residue, followed by drying and weighing. The ash content was quantified by slowly decomposing $\mathrm{CN}$ with concentrated nitric acid upon heating, followed by incinerating and weighing the calcined residue.

\subsubsection{Examination of $\mathrm{CN}$ Structure}

The surface morphology of $\mathrm{CN}$ fibers was studied, and IR spectroscopy of $\mathrm{CN}$ was performed by the same methods as for BNC.

Combined thermogravimetric (TGA) and differential thermal (DTA) analyses of $\mathrm{CN}$ were done on a TGA/DTG-60 thermal analyzer (Shimadzu, Japan) under the following conditions- $0.5 \mathrm{~g}$ sample weight, $10^{\circ} \mathrm{C} / \mathrm{min}$ heating rate, $350^{\circ} \mathrm{C}$ maximum temperature, and nitrogen as the inert environment.

${ }^{13} \mathrm{C}$ nuclear magnetic resonance (NMR) spectra of $\mathrm{CN}$ were recorded at $60{ }^{\circ} \mathrm{C}$ on a Bruker $\mathrm{AM}$ 400 spectrometer (Bruker, Germany) operating at $100.61 \mathrm{MHz}$. The chemical shifts of signals were referenced to DMSO- $\mathrm{d}_{6}$ as an internal standard.

\section{Results and Discussion}

\subsection{Biosynthesis of BNC}

The scaled up biosynthesis of BNC afforded $9432 \mathrm{~g}$ of BNC gel-films. Table 2 lists basic indicators of BNC biosynthesis by the Medusomyces gisevii Sa-12 symbiont in three cycles.

The BNC yield varied from $4.9 \%$ to $6.4 \%$ in three cycles. Because only the configuration of the vessels was varied, while the other parameters were kept unchanged, it can be inferred that the BNC yield depends on the thickness of the growth medium layer, that is, the thinner the layer of the medium, the higher the BNC yield: The thinnest layer of $2.9 \mathrm{~cm}$ in cycle I; a thicker layer of $3.7 \mathrm{~cm}$ in cycle III; and a yet thicker layer of $4.9 \mathrm{~cm}$ in cycle II (Table 1).

By comparing the yield of BNC prepared in vessels of 17-104 L in volume with the lab-scale yield of $6.8 \%$ obtained in the $0.5-\mathrm{L}$ vessel [26], one can state that the yield declined upon scaling up the biosynthesis of BNC. Despite the decrease in BNC yield during scale-up, a positive aspect was the 
absence of a relationship between the BNC yield and the number of cycles: For instance, the yield in the third cycle was higher than that in the second. Thus, the triple cyclic culturing with Medusomyces gisevii Sa-12 in nonsterile conditions was a success. The engineering aspects of this strategy should be further elaborated in order to obtain a high, stable yield of BNC with increasing the number of cycles.

Table 2. Basic indicators of BNC biosynthesis.

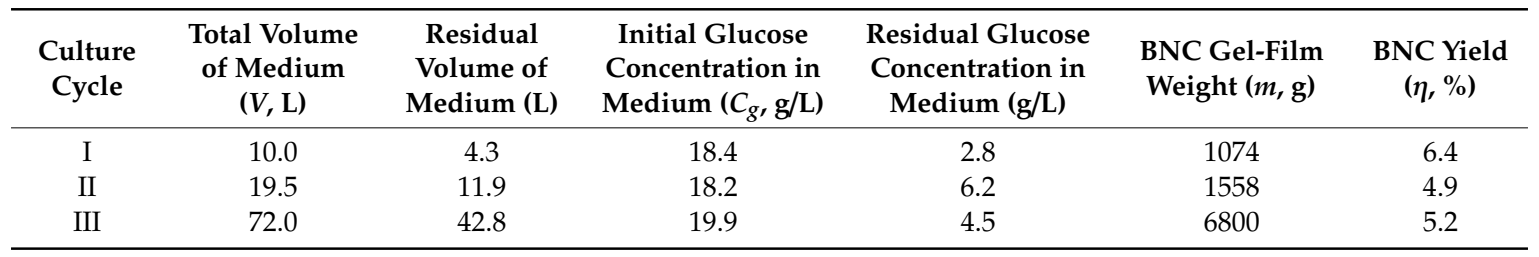

The change in glucose concentration during the biosynthesis of BNC is depicted in Figure 1.

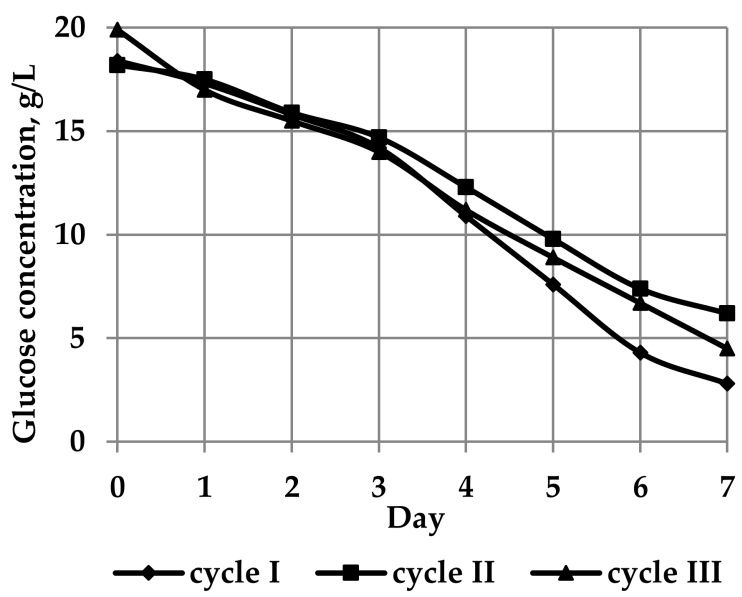

Figure 1. A time profile of glucose concentration during biosynthesis of BNC.

The residual glucose concentration indirectly indicated that the BNC yield varied in inverse proportion: The less glucose was left, the greater the BNC yield. The most representative sample of BNC weighing $6800 \mathrm{~g}$ and exhibiting an $\alpha$-cellulose content of $99 \%$ and a polymerization degree of 4000 was used for nitration.

\subsection{Nitration of $B N C$}

The key characteristics of the resultant $\mathrm{CN}$ are given in Table 3.

Table 3. Key properties of synthesized cellulose nitrate $(\mathrm{CN})$.

\begin{tabular}{ccccc}
\hline Sample Name & $\begin{array}{c}\text { Nitrogen Content } \\
(\%)\end{array}$ & $\begin{array}{c}\text { Viscosity of 2\% } \\
\text { CN-Acetone } \\
\text { Solution (sP) }\end{array}$ & $\begin{array}{c}\text { Solubility in the } \\
\text { Alcohol-Ester } \\
\text { Mixture (\%) }\end{array}$ & Ash Content (\%) \\
\hline BNC-based CN & 10.96 & 916 & 47 & 0.1 \\
\hline
\end{tabular}

The obtained CN sample had the following quality attributes-10.96\% nitrogen content, $916 \mathrm{cP}$ viscosity, $47 \%$ solubility in the alcohol-ester mixture, and $0.10 \%$ ash content. The solubility test of $\mathrm{CN}$ in acetone showed a $100 \%$ result.

The yield of CN was calculated as the weight of initial cellulose and was $158 \%$, which is due to the increase in the average molecular weight of the monomeric unit by incorporation of the nitro group.

The small nitrogen content of $10.96 \%$ can be attributed to the low reactivity of BNC, due to its lightweight. The lightweight rhombic pieces of BNC had a volumetric shape and were recalcitrant 
to impregnation with mixed acid, floating on the surface of the reaction mixture in spite of agitation. Thus, the diffusion of the nitronium cation into the BNC sample slowed down, in a similar manner described [13].

The findings differ significantly from those obtained for nitration of conventional plant cellulose. Conspicuous is the fact that the resultant BNC-based CN sample had a higher viscosity of $916 \mathrm{cP}$ versus 0.6-72 cP of industrial CNs [36] and versus 4-35 cP of plant CNs from Miscanthus [38,39], intermediate flax straw [40] and oat hulls [41], which were produced under similar conditions.

No doubt that the viscosity of BNC-based $\mathrm{CN}$ can be reduced to the required values by autoclaving under conditions harsher than those for plant cellulose-based $\mathrm{CN}$ [38-41]. The viscosity reduction will increase the solubility of BNC-based CN.

The substantial difference between characteristics of BNC-based CN and plant cellulose-based $\mathrm{CN}$ is due to the unique 3D reticulate structure, high degree of polymerization, and plate-like shape of BNC. Taking cognizance of the features of BNC-based CN, one should seek special fields of application in which high-viscosity properties of $\mathrm{CN}$ are required. It was found by measuring the viscosity (dissolution of $1 \mathrm{~g} \mathrm{CN}$ in $50 \mathrm{~mL}$ acetone) that BNC-based CN generated a transparent, highly viscous organogel that represents a continuous 3D macromolecular network serving as a framework whose voids are filled with low-molecular acetone. The potential application fields of this organogel have not yet been identified. Probably, the high purity and unique structure of BNC-based CN will allow it to be used in modern science-driven areas, for example, in adhesive formulations for gluing items and electronics components, in special-purpose nitrolacquers, etc.

\subsection{Analysis Results for BNC and CN Samples}

SEM images of BNC and BNC-based CN are displayed in Figure 2, showing that the reticulate structure of original BNC fibers retained during nitration.

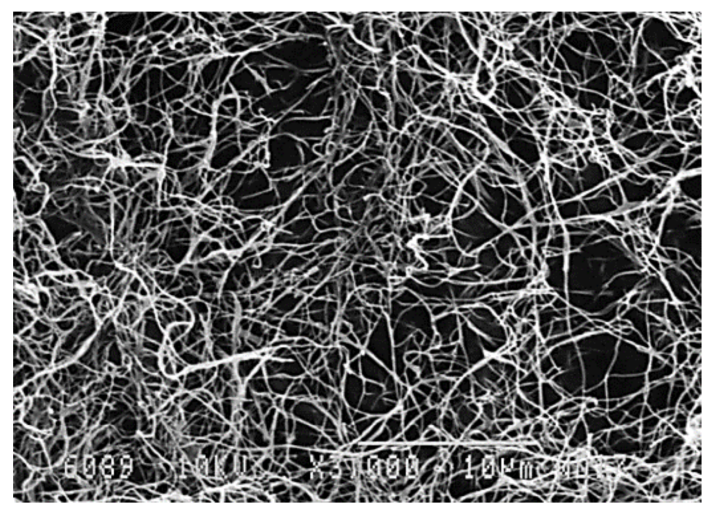

(a)

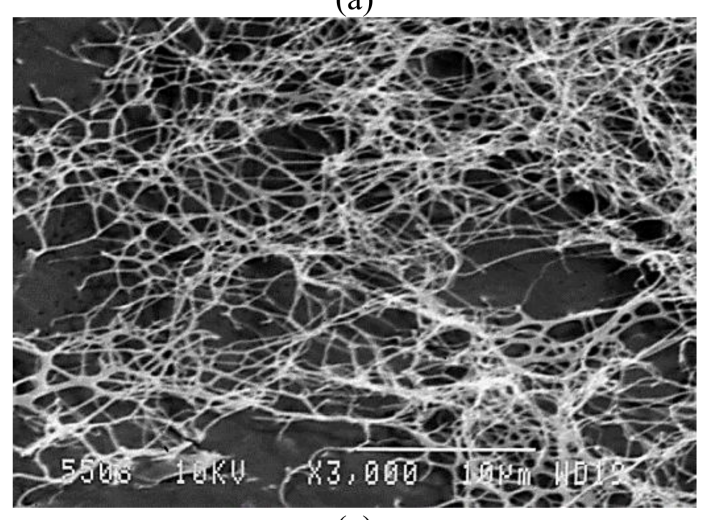

(c)

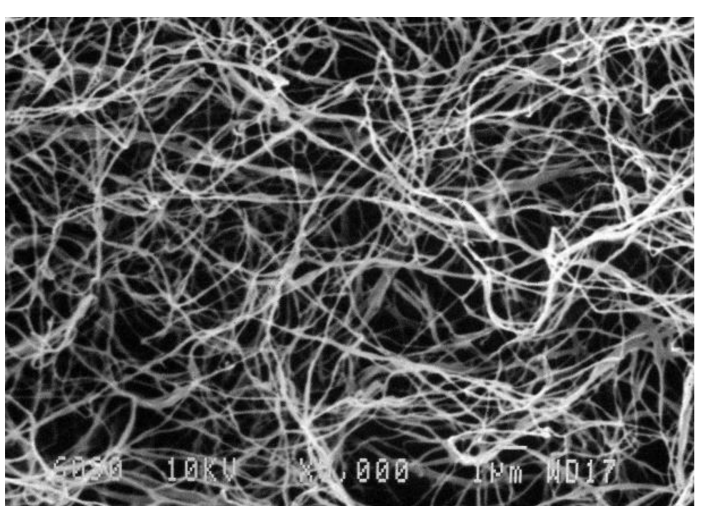

(b)

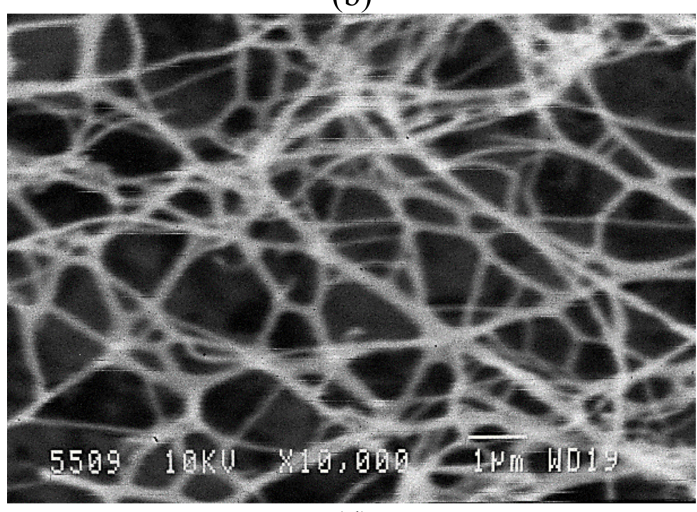

(d)

Figure 2. Scanning electron microscopy (SEM) images of (a,b) BNC and (c,d) BNC-based CN at zooms $\times 3000$ and $\times 10,000$, respectively. 
The average diameter of microfibrils of original BNC was $97 \mathrm{~nm}$ (a mean-square deviation of $21 \mathrm{~nm}$ ). The average diameter of $\mathrm{CN}$ fibers was $114 \mathrm{~nm}$ (a mean-square deviation of $22 \mathrm{~nm}$ ). Thus, as opposed to plant cellulose [41], the nitration of BNC almost did not enlarge the diameter of CN fibers.

Figure 3 shows the IR spectra of original BNC and BNC-based CN.

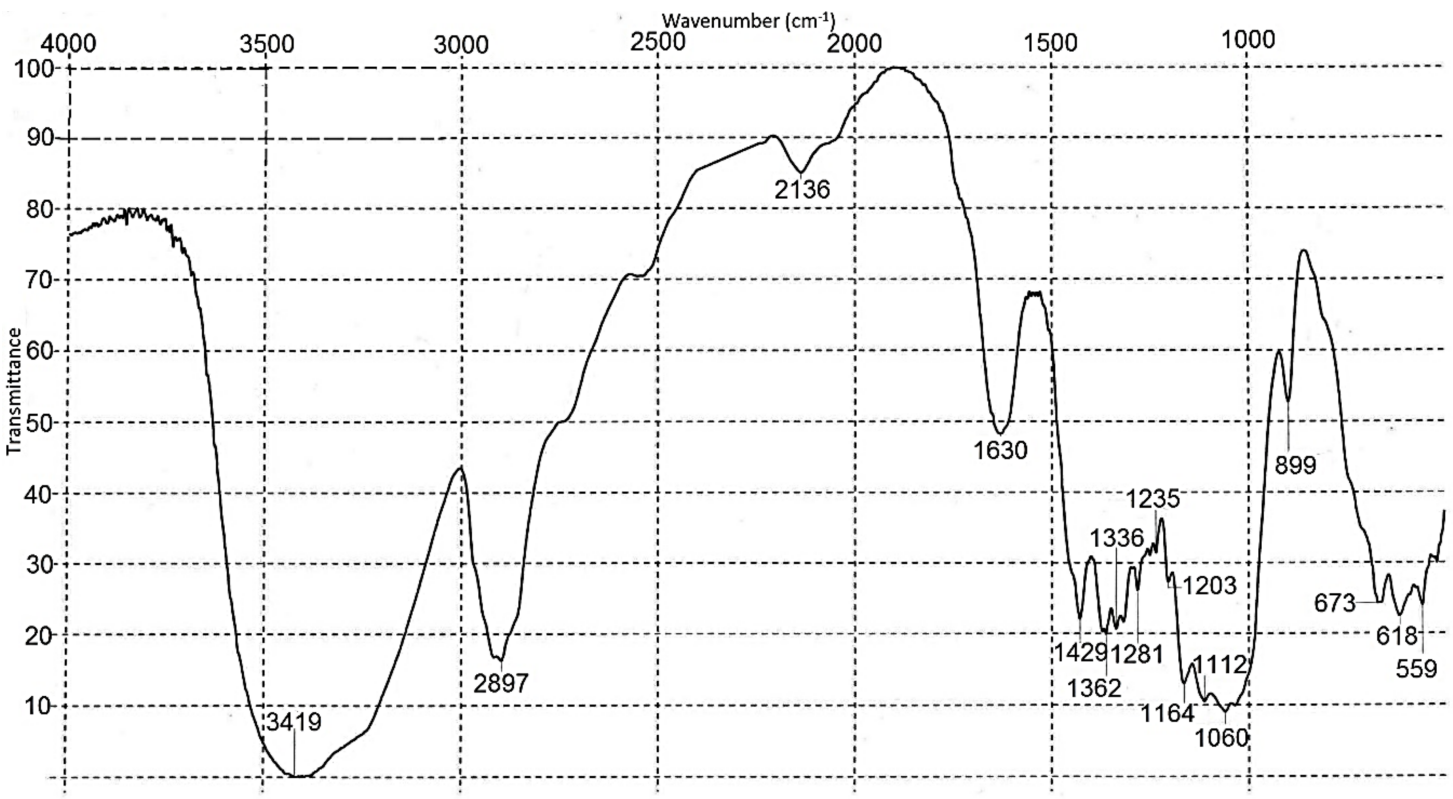

(a)

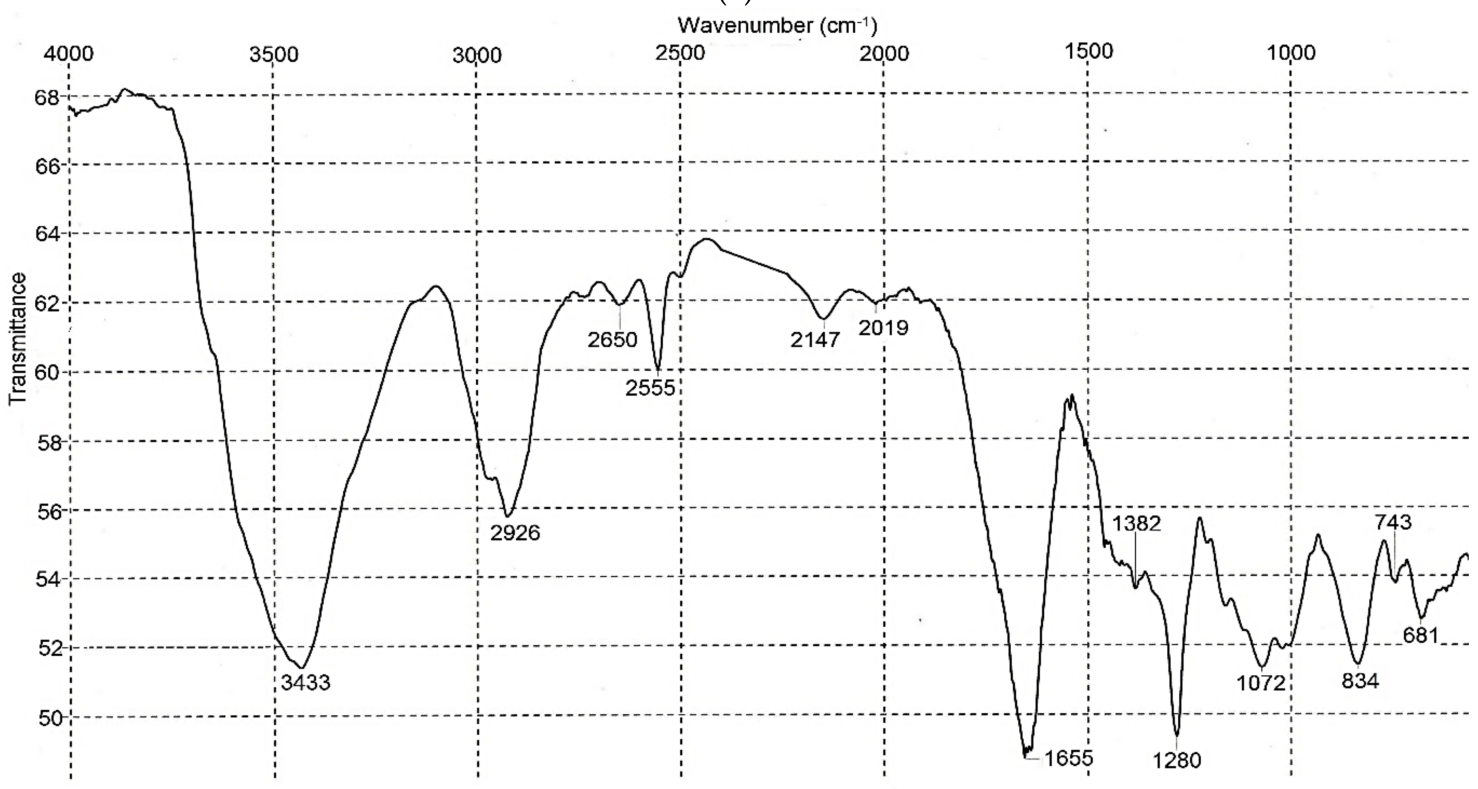

Figure 3. Infrared (IR) spectra of (a) BNC and (b) CN.

The IR spectra of BNC and CN show the basic characteristic frequencies of cellulose and CN [36,42-45]. The IR spectrum of original BNC had an intensive absorption band near $3419 \mathrm{~cm}^{-1}$, indicating $\mathrm{OH}$-group stretching. The IR spectrum of $\mathrm{CN}$ had absorption bands distinguishing it from that of initial BNC. In the region of the $\mathrm{OH}$-group $\left(3500 \mathrm{~cm}^{-1}\right)$, the IR spectrum of $\mathrm{CN}$ exhibited a much lower area compared to that of original BNC, suggesting only a partial substitution of OH-groups by $\mathrm{NO}_{2}$, which is in good agreement with the low nitrogen content of the resultant $\mathrm{CN}(10.96 \%)$. Besides, the following characteristic frequencies were detected in the IR spectrum of CN-2555, 1655, 1280, 834, 743 and $681 \mathrm{~cm}^{-1}$, which match the basic absorption bands of nitro groups [36,42]. Similar stretch 
vibrations were also found in the IR spectrum of BNC-based CN by Sun et al. [15]. The characteristic frequency of decomposition products of $\mathrm{CN}$ at $2300 \mathrm{~cm}^{-1}$ was missing.

In addition, the $\mathrm{CN}$ sample was evaluated by TGA/DTA and ${ }^{13} \mathrm{C}$ NMR spectroscopy. The TGA/ DTA scans of the BNC-based CN sample are displayed in Figure 4.

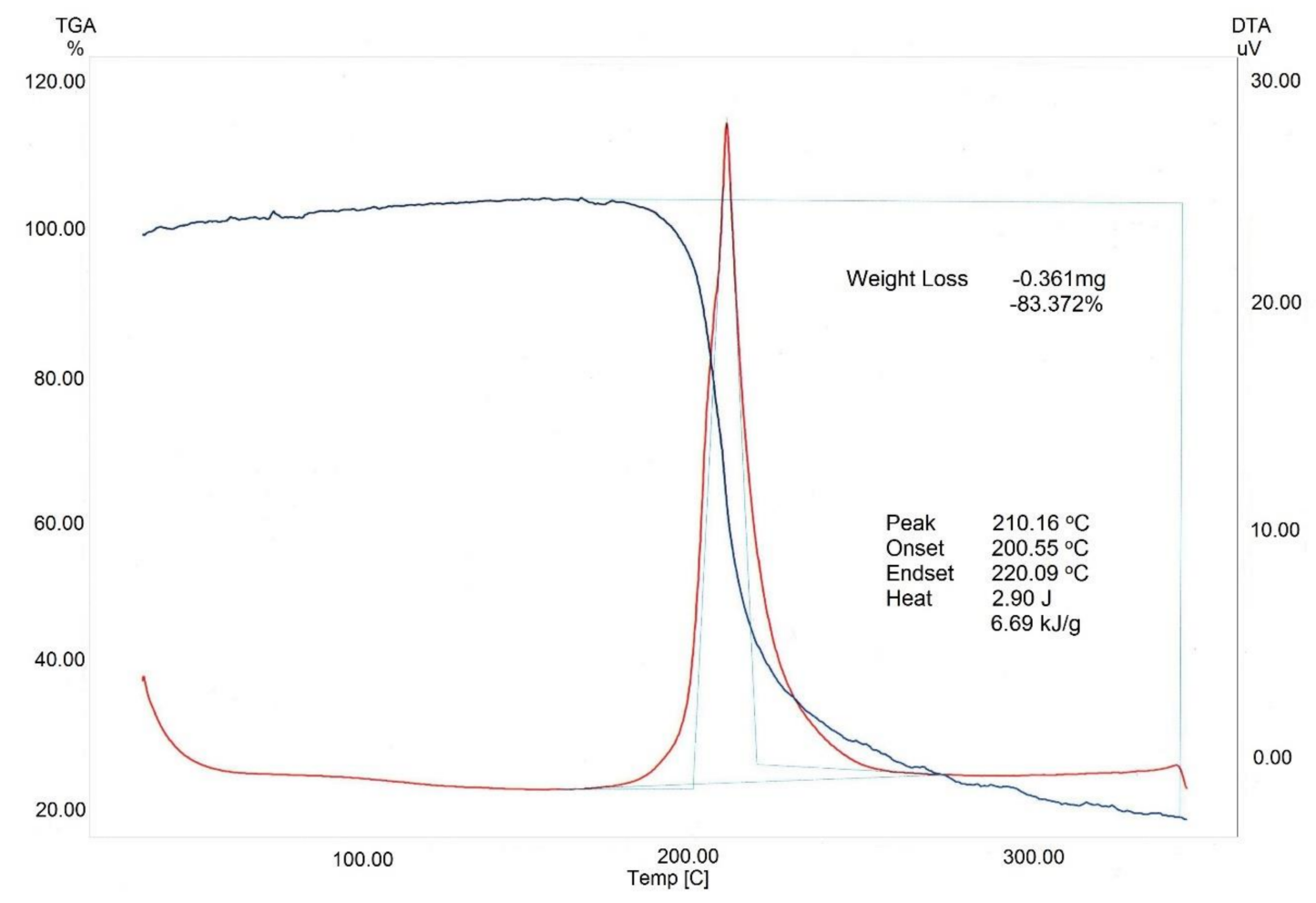

Figure 4. Thermogravimetric (TGA) and differential thermal (DTA) pattern of BNC-based CN.

The TGA/DTA analysis showed that the resultant $\mathrm{CN}$ sample had a high decomposition temperature. The TGA curve had one exothermic peak at $210{ }^{\circ} \mathrm{C}$, accompanied by the sample weight loss to $83 \%$. The onset temperature of decomposition of the synthesized $\mathrm{CN}$ sample was $200{ }^{\circ} \mathrm{C}$ and extended to $220^{\circ} \mathrm{C}$. The obtained results are on a par with the experimental data for TGA/DTA of BNC-based CN [15].

The ${ }^{13} \mathrm{C}$ NMR spectrum of the BNC-based CN sample is depicted in Figure 5.

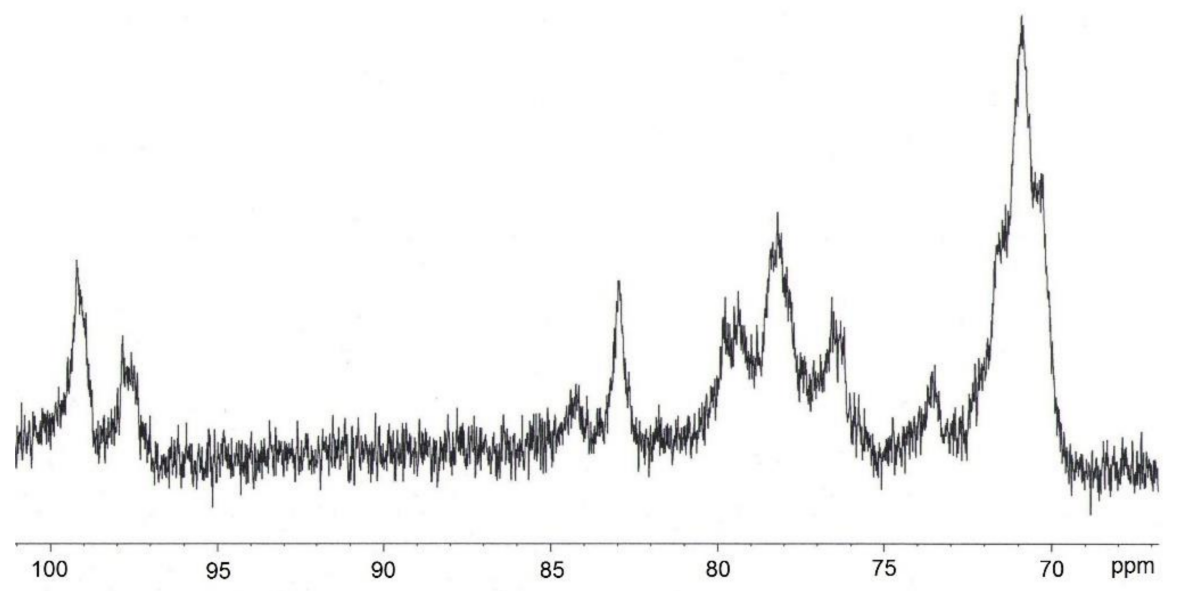

Figure 5. ${ }^{13} \mathrm{C}$ nuclear magnetic resonance (NMR) spectrum (DMSO- $\mathrm{d}_{6}$ ) of BNC-based CN. 
The NMR spectrum of BNC-based CN showed chemical shifts typical of 6-mononitrocellulose (76.6 ppm), 2,6-dinitrocellulose (97.8 ppm, $84.3 \mathrm{ppm}, 82.9 \mathrm{ppm}, 79.4 \mathrm{ppm}$ ), 3,6-dinitrocellulose (78.2 ppm) and 2,3,6-trinitrocellulose (99.2 ppm, $73.6 \mathrm{ppm}, 70.9 \mathrm{ppm}$ ) [46,47]. Overall, the $\mathrm{CN}$ samples contained 6-, 2,6-, 3,6- and 2,3,6-substituted moieties of the glucopyranose ring of the cellulose macromolecule. These findings match the results earlier obtained for the nitration of bacterial cellulose with mixed anhydrous $\mathrm{HNO}_{3}$ and dichloromethane [14].

The obtained results from our studies on the properties of $\mathrm{CN}$ derived from microbial cellulose suggest that new $\mathrm{CNs}$ can potentially be used in conventional and high-tech economic sectors. But these efforts can be justified only by scaling up the biosynthesis of BNC with stable characteristics of BNC from worthless non-food plant biomass using a cellulose-producing strain with a high-level adaptation and a high tolerance to contamination [48], which is being planned to be done in the future.

\section{Conclusions}

The three-cycle biosynthesis of BNC by the Medusomyces gisevii Sa-12 symbiont with increasing volume of the nutrient medium from 10 to $72 \mathrm{~L}$ was successfully scaled up in nonsterile conditions to furnish $9432 \mathrm{~g}$ of BNC gel-films. The 6800-g BNC sample chosen for nitration exhibited an $\alpha$-cellulose content of $99 \%$ and a polymerization degree of 4000 . CNs having a nitrogen content of $10.96 \%$ and a viscosity of $916 \mathrm{cP}$ were synthesized by nitration of freeze-dried BNC with sulfuric-nitric mixed acid. It was found by comparing the surface morphologies of $\mathrm{BNC}$ and $\mathrm{CN}$ fibers that the $3 \mathrm{D}$ reticulate structure of original BNC retained in full with the nanofibers themselves thickened marginally. Different techniques, such as IR, TGA/DTA, and ${ }^{13} \mathrm{C}$ NMR, verified that the resultant nitration product was $\mathrm{CN}$. The $\mathrm{CN}$, when dissolved in acetone, was found to generate a clear high-viscosity organogel whose further studies will likely open up new application fields of $\mathrm{CN}$.

Author Contributions: Conceptualization, V.V.B., investigation, Y.A.G., G.F.M., E.K.G., E.I.K., N.A.S., D.S.G., I.N.P., O.V.B.; methodology, E.A.S., E.K.G., Y.A.G., A.A.K.; writing-original draft preparation, Y.A.G., G.F.M.; writing—review and editing, V.V.B., E.A.S.; visualization, N.V.B., G.F.M., Y.A.G.; supervision, V.V.B., G.V.S.

Funding: This research was funded by the Russian Science Foundation, grant number 17-19-01054

Acknowledgments: The research was supported by the Biysk Regional Center for Shared Use of Scientific Equipment (IPCET SB RAS, Biysk).

Conflicts of Interest: The authors declare no conflict of interest.

\section{References}

1. Gama, M.; Dourado, F.; Bielecki, S. (Eds.) Bacterial Nanocellulose: From Biotechnology to Bio-Economy; Elsevier: Oxford, UK, 2016; p. 260.

2. Khan, S.; Ul-Islam, M.; Khattak, W.A.; Ullah, M.W.; Park, J.K. Bacterial cellulose-titanium dioxide nanocomposites: Nanostructural characteristics, antibacterial mechanism, and biocompatibility. Cellulose 2014, 22, 565-579. [CrossRef]

3. Moniri, M.; Moghaddam, A.B.; Azizi, S.; Rahim, R.A.; Bin Ariff, A.; Saad, W.Z.; Navaderi, M.; Mohamad, R. Production and Status of Bacterial Cellulose in Biomedical Engineering. Nanomaterials 2017, 7, 257. [CrossRef]

4. Zaborowska, M.; Bodin, A.; Bäckdahl, H.; Popp, J.; Goldstein, A.; Gatenholm, P. Microporous bacterial cellulose as a potential scaffold for bone regeneration. Acta Biomater. 2010, 6, 2540-2547. [CrossRef] [PubMed]

5. Gorgieva, S.; Trček, J. Bacterial Cellulose: Production, Modification and Perspectives in Biomedical Applications. Nanomaterials 2019, 9, 1352. [CrossRef] [PubMed]

6. Li, Q.; Wang, Y.; Wu, Y.; He, K.; Li, Y.; Luo, X.; Li, B.; Wang, C.; Liu, S. Flexible cellulose nanofibrils as novel pickering stabilizers: The emulsifying property and packing behavior. Food Hydrocoll. 2019, 88, 180-189. [CrossRef]

7. Liu, Y.-S.; Bai, Y.-L.; Liu, X.; Ma, C.; Wu, X.-Y.; Wei, X.; Wang, Z.; Wang, K.-X.; Chen, J.-S. Free-Standing Hybrid Porous Membranes Integrated with Transition Metal Nitride and Carbide Nanoparticles for High-Performance Lithium-Sulfur Batteries. Chem. Eng. J. 2019, 378, 122208. [CrossRef] 
8. Shim, E.; Su, J.; Noro, J.; Teixeira, M.A.; Cavaco-Paulo, A.; Silva, C.; Kim, H.R. Conductive bacterial cellulose by in situ laccase polymerization of aniline. PLOS ONE 2019, 14, e0214546. [CrossRef]

9. Wang, J.; Tavakoli, J.; Tang, Y. Bacterial cellulose production, properties and applications with different culture methods-A review. Carbohydr. Polym. 2019, 219, 63-76. [CrossRef]

10. Hu, W.; Chen, S.; Yang, J.; Li, Z.; Wang, H. Functionalized bacterial cellulose derivatives and nanocomposites. Carbohydr. Polym. 2014, 101, 1043-1060. [CrossRef]

11. Luo, Q.; Zhu, J.; Li, Z.; Duan, X.; Pei, C.; Mao, C. The Solution Characteristics of Nitrated Bacterial Cellulose in Acetone. New J. Chem. 2018, 42, 18252-18258. [CrossRef]

12. Chai, H.; Duan, Q.; Jiang, L.; Gong, L.; Chen, H.; Sun, J. Theoretical and experimental study on the effect of nitrogen content on the thermal characteristics of nitrocellulose under low heating rates. Cellulose 2019, 26, 763-776. [CrossRef]

13. Nikolsky, S.N.; Zlenko, D.V.; Melnikov, V.P.; Stovbun, S.V. The fibrils untwisting limits the rate of cellulose nitration process. Carbohydr. Polym. 2019, 204, 232-237. [CrossRef] [PubMed]

14. Yamamoto, H.; Horii, F.; Hirai, A. Structural studies of bacterial cellulose through the solid-phase nitration and acetylation by CP/MAS ${ }^{13} \mathrm{C}$ NMR spectroscopy. Cellulose 2006, 13, 327-342. [CrossRef]

15. Sun, D.-P.; Ma, B.; Zhu, C.-L.; Liu, C.-S.; Yang, J.-Z. Novel nitrocellulose made from bacterial cellulose. J. Energ. Mater. 2010, 28, 85-97. [CrossRef]

16. Peters, G.; Endsor, R.; Hamid, J.; Claridge, R.; Arber, A.; Dennis, C. Nitration of Bacterial Cellulose. In Proceedings of the 5th International Nitrocellulose Symposium, Spiez, Switzerland, 17-18 April 2012; p. 40.

17. Foresti, M.L.; Vázquez, A.; Boury, B. Applications of bacterial cellulose as precursor of carbon and composites with metal oxide, metal sulfide and metal nanoparticles: A review of recent advances. Carbohydr. Polym. 2017, 157, 447-467. [CrossRef]

18. Gomes, F.P.; Silva, N.H.; Trovatti, E.; Serafim, L.S.; Duarte, M.F.; Silvestre, A.J.; Freire, C.S. Production of bacterial cellulose by Gluconacetobacter sacchari using dry olive mill residue. Biomass Bioenerg. 2013, 55, 205-211. [CrossRef]

19. Krystynowicz, A.; Czaja, W.; Wiktorowska-Jezierska, A.; Gonçalves-Miśkiewicz, M.; Turkiewicz, M.; Bielecki, S. Factors affecting the yield and properties of bacterial cellulose. J. Ind. Microbiol. Biot. 2002, 29, 189-195. [CrossRef]

20. Hussain, Z.; Sajjad, W.; Khan, T.; Wahid, F. Production of bacterial cellulose from industrial wastes: A review. Cellulose 2019, 26, 2895-2911. [CrossRef]

21. Marsh, A.J.; O'Sullivan, O.; Hill, C.; Ross, R.P.; Cotter, P.D. Sequence-based analysis of the bacterial and fungal Compositions of multiple kombucha (tea fungus) samples. Food Microbiol. 2014, 38, 171-178. [CrossRef]

22. Kutyshenko, V.P.; Yurkevich, D.I. Influence of heavy water on the metabolism of a symbiotic organism. Biophysics 2003, 48, 648-656.

23. Kiziltas, E.E.; Kiziltas, A.; Gardner, D.J. Synthesis of bacterial cellulose using hot water extracted wood sugars. Carbohydr. Polym. 2015, 124, 131-138. [CrossRef] [PubMed]

24. Aleshina, L.A.; Gladysheva, E.K.; Budaeva, V.V.; Skiba, E.A.; Arkharova, N.A.; Sakovich, G.V. X-ray Diffraction Study of Bacterial Nanocellulose Produced by the Medusomyces Gisevii Sa-12 Culture in Enzymatic Hydrolysates of Oat Hulls. Crystallogr. Rep. 2018, 63, 955-960. [CrossRef]

25. Aleshina, L.A.; Gladysheva, E.K.; Budaeva, V.V.; Golubev, D.S.; Skiba, E.A.; Sakovich, G.V. X-ray Diffraction Study of Bacterial Nanocellulose Produced by Medusomyces Gisevii Sa-12 Cultured in Enzymatic Hydrolysates of Miscanthus. Crystallogr. Rep. 2019, 64, 914-919. [CrossRef]

26. Gladysheva, E.K.; Skiba, E.A.; Zolotukhin, V.N.; Sakovich, G.V. Study of the Conditions for the Biosynthesis of Bacterial Cellulose by the Producer Medusomyces gisevii Sa-12. Appl. Biochem. Microbiol. 2018, 54, 179-187. [CrossRef]

27. Goh, W.N.; Rosma, A.; Kaur, B.; Fazilah, A.; Karim, A.A.; Rajeev, B. Fermentation of black tea broth (Kombucha): I. Effects of sucrose concentration and fermentation time on the yield of microbial cellulose. Int. Food Res. J. 2012, 19, 109-117.

28. Budhiono, A.; Rosidi, B.; Taher, H.; Iguchi, M. Kinetic aspects of bacterial cellulose formation in nata-de-coco culture system. Carbohydr. Polym. 1999, 40, 137-143. [CrossRef]

29. Miller, G.L. Use of dinitrosalicylic acid reagent for determination of reducing sugar. Anal. Chem. 1959, 31, 426-428. [CrossRef] 
30. McKenna, B.A.; Mikkelsen, D.; Wehr, J.B.; Gidley, M.J.; Menzies, N.W. Mechanical and structural properties of native and alkalitreated bacterial cellulose produced by Gluconacetobacter xylinus strain ATCC 53524. Cellulose 2009, 16, 1047-1055. [CrossRef]

31. Younesi, M.; Wu, X.; Akkus, O. Controlled mercerization of bacterial cellulose provides tunability of modulus and ductility over two orders of magnitude. J. Mech. Behav. Biomed. Mater. 2019, 90, 530-537. [CrossRef]

32. Hestrin, S.; Schramm, M. Synthesis of cellulose by Acetobacter xylinum: II. Preparation of freeze-dried cells capable of polymerizing glucose to cellulose. Biochem. J. 1954, 58, 345-352. [CrossRef]

33. Chandrasekaran, P.T.; Bari, N.K.; Sinha, S. Enhanced bacterial cellulose production from Gluconobacter xylinus using super optimal broth. Cellulose 2017, 24, 4367-4381. [CrossRef]

34. Obolenskaya, A.V.; Yelnitskaya, Z.P.; Leonovich, A.A. Laboratornye Raboty po Khimii Drevesiny I Tsellyulozy [Laboratory Works on Wood and Cellulose Chemistry]: Textbook for Higher Educational Institutions; Ecology Publisher: Moscow, Russia, 1991; p. 72. (In Russian)

35. Hallac, B.B.; Ragauskas, A.J. Analyzing cellulose degree of polymerization and its relevancy to cellulosic ethanol. Biofuels Bioprod. Biorefining 2011, 5, 215-225. [CrossRef]

36. Novyi Spravochnik Khimika i Tekhnologa. Syr'e i Produkty Promyshlennosti Organicheskikh i Neorganicheskikh Veshchestv; [New Reference Book for Chemist and Engineer. Feedstock and Products of Organic and Inorganic Industry]; NPO Professional Publisher: St. Petersburg, Russia, 2006; p. 1142. (In Russian)

37. Gensh, K.V.; Kolosov, P.V.; Bazarnova, N.G. Quantitative analysis of cellulose nitrates by Fourier transform infrared spectroscopy. Russ. J. Bioorg. Chem. 2011, 37, 814-816. [CrossRef]

38. Gismatulina, Y.A.; Budaeva, V.V.; Sakovich, G.V. Nitrocellulose Synthesis from Miscanthus Cellulose. Propellants Explos. Pyrotech. 2018, 43, 96-100. [CrossRef]

39. Gismatulina, Y.A.; Budaeva, V.V.; Sakovich, G.V. Nitric acid preparation of cellulose from miscanthus as a nitrocellulose precursor. Russ. Chem. Bull. 2015, 64, 2949-2953. [CrossRef]

40. Gismatulina, Y.A.; Budaeva, V.V.; Sakovich, G.V. Cellulose nitrates from intermediate flax straw. Russ. Chem. Bull. 2016, 65, 2920-2924. [CrossRef]

41. Sakovich, G.V.; Budaeva, V.V.; Korchagina, A.A.; Gismatulina, Y.A. Prospects of cellulose nitrates from unconventional feedstocks for use in composite explosives. Khimiya Rastit. Syrya Chem. Plant Raw Mater. 2019, 1, 259-268. (In Russian) [CrossRef]

42. Kovalenko, V.I.; Sopin, V.F.; Khrapkovskii, G.M. Strukturno-Kineticheskie Osobennosti Polucheniia $i$ Termodestruktsii Nitratov Tselliuloz [Structural and Kinetic Features of Preparation and Thermal Degradation of Cellulose Nitrate]; Nauka: Moscow, Russia, 2005; p. 213. (In Russian)

43. Luo, L.; Jin, B.; Xiao, Y.; Zhang, Q.; Chai, Z.; Huang, Q.; Chu, S.; Peng, R. Study on the isothermal decomposition kinetics and mechanism of nitrocellulose. Polym. Test. 2019, 75, 337-343. [CrossRef]

44. Moore, D.S.; McGrane, S.D. Comparative infrared and Raman spectroscopy of energetic polymers. J. Mol. Struct. 2003, 661-662, 561-566. [CrossRef]

45. De la Ossa, M.Á.F.; López-López, M.; Torre, M.; García-Ruiz, C. Analytical techniques in the study of highly-nitrated nitrocellulose. Trac-Trend. Anal. Chem. 2011, 30, 1740-1755. [CrossRef]

46. Kovalenko, V.I.; Marchenko, G.N.; Khrapkovskii, G.M.; Shamov, A.G. Stroenie, Sintez i Termicheskoe Razlozhenie Nitratov Cellyulozy [The Structure, Synthesis and Thermal Decomposition of Cellulose Nitrates]; KDU: Moscow, Russia, 2012; p. 396. (In Russian)

47. Trache, D.; Khimeche, K.; Mezroua, A.; Benziane, M. Physicochemical properties of microcrystalline nitrocellulose from Alfa grass fibres and its thermal stability. J. Therm. Anal. Calorim. 2016, 124, 1485-1496. [CrossRef]

48. Skiba, E.A.; Budaeva, V.V.; Ovchinnikova, E.V.; Gladysheva, E.K.; Kashcheyeva, E.I.; Pavlov, I.N.; Sakovich, G.V. A technology for pilot production of bacterial cellulose from oat hulls. Chem. Eng. J. 2019. [CrossRef]

(C) 2019 by the authors. Licensee MDPI, Basel, Switzerland. This article is an open access article distributed under the terms and conditions of the Creative Commons Attribution (CC BY) license (http://creativecommons.org/licenses/by/4.0/). 